\title{
Public Opinion Research Data on the Entry of the Czech Republic into NATO*
}

\author{
PETR MAREŠ ${ }^{* *}$ \\ Faculty of Social Studies, Masaryk University, Brno
}

\begin{abstract}
This article was written in 1998, that is, before the Czech Republic was formally accepted as a member of NATO in March 1999. It is a classic secondary analysis of published results from public opinion polls, examining attitudes toward NATO among the Czech population. Support for and opposition to NATO entry closely corresponds to the political orientation of respondents, dividing right from left. This distinguishes the Czech Republic from Poland, where support for the country's application for NATO membership also issues from a substantial part of leftoriented voters. Those against Czech membership are not only individuals with a leftist orientation, but also nationalists. This analysis of public opinion research data attempts to identify how responses to questions about the consequences of NATO entry can sort people (whose attitude towards NATO is not known to us) into groups of supporters and opponents of the Czech Republic joining NATO.

Czech Sociological Review, 2000, Vol. 8 (No. 1: 103-116)
\end{abstract}

\section{The Goal and Method}

The story of NATO expansion can, according to Steven Kull [1997], be seen from two angles. The first of these develops around the theme of the triumph of the West over communism and understands the expansion of NATO in the context (and discourse) of the Cold War as its completion and the securing of victory in its defence of freedom and democracy. However, it can also be seen as a precaution against any possible threat arising out of a revival of Russian authoritarian culture, which is now debilitated. This sec-

\footnotetext{
*) Granted by the Ministry of Foreign Affairs of the Czech Republic (RB3/7/98). I would like to express my gratitude to all those who consented to share the findings of their polls with me. Namely to: Hungary - Dr. Erika Hlédik (Szonda Ipsos, Budapest), Dr. György Fischer (Gallup Hungary, Budapest), Dr. Ildikó Csöngei (ELTE University, Budapest). Poland - Prof. BobińskaKolarska (Instytut Spraw publicznych, Warsawa), Doc. Krzystof Zagórski (CBOS - Centrum Badań Opinii Spolecznej, Warszawa), Dr. Wojciech Pawlak (Ośrodiek Badań Opinii Publicznej, Warszawa), Dr. Eugeniusz Śmialowski (Pentor, Warsawa). The Slovak Republic - Dr. František Szabó (Ústav pre výskum verejnej mienky pri Štatistickom úrade Slovenskej republiky, Bratislava), Dr. Zora Bútorová (IVO - Inštitút pre verejne otázky, Bratislava), Dr. Ivan Dianiška (FOCUS - Centrum pre sociálnu a marketingovu analýzu, Bratislava), Dr. Iveta Radičová (SPACE, Bratislava). The Czech Republic - Dr. Jan Hartl (STEM - Středisko empirických výzkumů̊, Praha), Dr. Eliška Rendlová (Institut pro výzkum veřejného mínění při Statistickém úřadu České republiky), Dr. Jan Herzmann (Sofres-Eactum, Praha), Dr. Štefan Sarvaš (Hlavní personální úřad Ministerstva národní obrany České republiky). I am also very grateful to all research institutes that have published their papers on this issue on the Internet (namely to Eurostat a Eurobarometer, National Defense University in the USA, USIA - United States Information Agency).

**) Direct all correspondence to Petr Mareš, associate professor, Department of Sociology, Faculty of Social Studies, Masaryk University, Gorkého 7, 60200 Brno, The Czech Republic, e-mail pmares@fss.muni.cz
} 
ond view understands the expansion of the NATO as the creation of a new system of collective security with as many co-operating European countries involved as is possible. In this scenario, neither the Cold War nor Russia are the core issues. These are mutual assistance, communication and trade, and both regional and global security, without the creation of new borders or excluding anybody. The question is, how are these two stories reflected in the public opinion of the member countries of NATO, and in the public opinion of countries that aspire to become members? What are the motivations in support of the extension of the North Atlantic Treaty Organisation, and what leads people to oppose such a step? What is the proportion of factors supporting or rejecting entry into NATO among candidate countries? What discourse is used by the general population in the discussion on NATO?

An attempt to answer such questions is the goal of this paper, which is a classic secondary analysis of published results from public opinion research, and in some cases an analysis of primary data collected by agencies conducting research on public opinion (namely STEM - the Centre for Empirical Research, IVVM - Institute for Public Opinion Polls and Sofres-Factum in the Czech Republic, and Focus agency in Slovakia). Our goal was:

- to extract the most substantial information from a mosaic of hundreds of published partial reports;

- to reconstruct the chronology and continuity of information (research on the topic of NATO entry has been conducted in most of the post-communist countries since the beginning of the 1990s, and at least some of the questions asked appear in various omnibus research with a certain periodicity);

- to use hitherto unutilised information available from primary data, using sophisticated analysis.

\section{Context - Public Opinion in the Member Countries}

Among the population of the US, support for NATO expansion seems relatively high. However, the admittance of new countries into NATO does not seem as urgent a need to the public of the United States as to the people of the countries discussed. The transformation of NATO is not understood here as an opportunity to take an advantage of the weakness of Russia and to strengthen themselves against its threat, nor even as an expression of American financial interests. The American public want NATO to continue to exist, but there is a growing conviction about the need to transform NATO to reflect its new environment ready to face new tasks. There is a growing stress put on changing this original defence alliance into a guarantee of a system of international security. And this should be done not only in a wider regional perspective, but also in regulating relations and potential conflicts among its member states. NATO is required to become an institution supporting democracy, facing up to aggression or terrorism, and solving potential ethnic and other conflicts wherever they may occur. ${ }^{1}$

Among the American public, the opinion is that the more countries participate in NATO co-operation, the better chance there is for sustaining peace. Nevertheless, other moral - commitments towards acceptance of the Eastern European countries are also taken into consideration. Conversely, there are some pragmatic reasons at work against

1) These expectations extend beyond the NATO Charter. 
their acceptance; mainly worries about the growing burden on the USA. The call from the American public for a reassessment of the function and purpose of NATO has a dual effect. On the one hand, it is for NATO expansion (in the expectation of enlarging the sphere of the 'safe world' by including other countries into it), on the other hand, it is against its expansion (leading to a willingness to transform NATO into something that goes beyond the borders of a classic defence pact - for example, by even being ready to accept Russia). The American public do not differentiate much among the individual applicant countries, not having favourites for the first wave of extension.

The public of the Western European NATO member countries differentiates to a larger extent than the American public among applicant countries. The one exception to this is the Italian public, whose attitude resembles that of the Americans. However, even with this exception it seems clear that NATO expansion is perceived by its European members more in its geopolitical dimensions as a move of its borders further to the east of Europe. This is very clear in the case of Germany. The public opinion polls of member countries do not seriously consider the acceptance of Russia and Ukraine, nor even Rumania and Bulgaria, and a bit surprisingly, not even Slovenia and the Baltic countries. This indicates that the public of European member countries are concerned about expanding NATO into regions where their interests may clash with others (mostly Russian), or into regions that neighbour unstable regions.

Such considerations are also affected by traditional relationships between applicant and member countries. There is a trinity of most acceptable new entrants, where the Czech Republic stands highest in the public opinion polls of Great Britain (although Poland occupies first place) and Germany. Nevertheless, Germany is generally sceptical as far as NATO expansion is concerned, as all the applicant countries have failed to gain acceptance. As far as traditional international connections are concerned there is a surprising prevalence of disapproval with the entry of the Czech Republic among the French public. This disagreement could be explained by a generally cautious attitude of the French public towards NATO expansion. We should take into an account here though that Hungary and especially Poland stand substantially higher in the public opinion of France.

\section{Post-Communist Countries}

At first glance, it is clear that ambitions to enter NATO (and also the European Community) are especially strong among the Polish public, which has traditionally had a tense relationship with Russia. Such ambitions are nevertheless high elsewhere, in countries where people see NATO as wonder-solution to all their problems. Their efforts to join NATO are not so much to provide security for the country as to lift it up from its postcommunist misery and to provide permanent and primarily quick welfare (e.g. Romania and Albania). This aim, without regard to its actual chances of being fulfilled, has become prevalent throughout the whole society of these countries, from right to left, from the high to low educated, from urban to remote rural inhabitants.

In contrast to these countries the populations of Hungary and the Czech Republic, and even Slovakia, judge NATO expansion with more sobriety. Public opinion in these countries is polarised. They consider not only the positive effects of the prospective entry into NATO, but also its costs. The attitude of the public in these countries towards NATO admittance has not been so unconditionally positive. Along with the section of the society that supports such a step there are numerous groups of its opponents. The basic axes that 
differentiate attitudes towards NATO in these countries are political orientation (from left to right of the spectrum) and the rate of nationalism. Those against NATO membership are not only individuals with a leftist orientation (in the Czech Republic the communist rhetoric is mixed up with nationalistic overtones, as it is in Slovakia and Hungary, but not in Poland) but also nationalists (in Slovakia and Hungary, while in the Czech Republic pure nationalistic sentiment is reduced to a marginal populist Republican party).

The public of the applicant countries want, in contrast to that of the American and Western-European member countries who expect some change in NATO goals (widely understood as collective safety), to enter the 'old' NATO. From it they expect guarantees against the expansionism of Russia (the discourse of the Cold War - Russia is evidently perceived more as an adversary than a partner worthy of co-operation). The public hopes not only to gain external security but also internal stability. NATO membership is understood as a completion of the transformation of society, that is, as a guarantee of its irreversibility. Economic reasons also play a role here. For advocates in the Czech Republic, Slovakia and Hungary, NATO membership means the first step towards prosperity and an admission ticket to the European Community. Indeed, some people in these countries see its benefits more in economic rather than security terms.

\section{The Czech Republic}

Czech public support for its NATO application is not particularly high, reflecting the differentiation of the population around not only this question. In this respect, the country belongs among such post-communist countries as Hungary and Slovakia, rather than countries such as Romania and Poland, where support for NATO cuts across the entire social and political spectrum. Nevertheless, support from the Czech public to enter NATO has risen over the last two years and currently stands at around 50-55\%. About $25-30 \%$ of the population are against entry, with about $15-20 \%$ undecided. It is worthy of note that together with Slovakia and Slovenia, the Czech Republic has relatively the highest proportion of people who would vote No to NATO accession in the case of a referendum.

Table 1. Long-term support for the Czech Republic's application to enter NATO (in percentage points) ${ }^{2}$

"Do you agree with the Czech Republic's entry into the North Atlantic Treaty Organisation?"

\begin{tabular}{lcccccccccccc} 
& \multicolumn{10}{c}{ Month/Year } & & \\
& $10 / 91$ & $05 / 93$ & $11 / 93$ & $11 / 94$ & $11 / 95$ & $11 / 96$ & $11 / 97$ & $1 / 98$ & $04 / 98$ & $07 / 98$ & $09 / 98$ & $12 / 98$ \\
\hline yes & 39 & 42 & 47 & 42 & 46 & 38 & 43 & 54 & $* 50$ & 51 & 55 & 51 \\
no & 40 & 36 & 27 & 28 & 39 & 36 & 29 & 24 & 27 & 32 & 26 & 30 \\
don't know & 21 & 22 & 26 & 30 & 15 & 26 & 28 & 22 & 23 & 17 & 19 & 19 \\
\hline
\end{tabular}

Source: $\quad$ Research by the Institute for Public Opinion Polls (IVVM) of the Czech Statistical Office.

2) In March 1998, about 57\% of respondents answered Yes to a similar question formulated in the research by Středisko... (STEM - Centre for Empirical Research) in Prague (No 38\%, and 5\% do not know). The question was formulated one way though: "Do you agree with the admittance of the Czech Republic into the NATO?" 
Table 2. Support for the Czech Republic's attempts to join NATO in 1998 (in percentage points)

"Do you agree with the Czech Republic's entry into the North Atlantic Treaty Organisation?”

\begin{tabular}{lllllllllllll} 
& \multicolumn{1}{c}{} & \multicolumn{1}{c}{ Year 1998 (Months) } \\
& 01 & 02 & 03 & 04 & 05 & 06 & 07 & 08 & 09 & 10 & 11 & 12 \\
\hline strongly agree & 26 & 23 & 25 & 22 & 25 & 20 & 25 & 25 & 19 & 26 & 21 & 16 \\
mostly agree & 28 & 32 & 29 & 28 & 30 & 31 & 30 & 30 & 36 & 31 & 29 & 35 \\
mostly disagree & 14 & 15 & 14 & 15 & 17 & 19 & 19 & 19 & 16 & 15 & 17 & 17 \\
strongly disagree & 10 & 11 & 10 & 12 & 12 & 13 & 13 & 13 & 10 & 11 & 13 & 13 \\
don't know & 22 & 19 & 22 & 23 & 16 & 17 & 17 & 13 & 19 & 17 & 20 & 19 \\
\hline
\end{tabular}

Source: $\quad$ Research by the Institute for Public Opinion Polls (IVVM) of the Czech Statistical Office.

What is specific for the Czech public is their polarisation into internally consistent attitudes for and against NATO entry. This is more a tension between positive and undecided attitudes in most of the applicant countries. Yet here we can also expect a high latent resistance to NATO integration among the undecided. In the Czech Republic, the line dividing support and resistance to NATO entry among the population runs straight between the left and right. ${ }^{3}$ This distinguishes the Czech Republic from Poland, where support also comes from a substantial part of left-oriented voters. This brings the Czech Republic closer to Hungary and Slovakia, with the difference that in these countries the resistance towards NATO entry is not concentrated among left-wing voters, but also among numerous nationalists. In contrast to Hungary and to Slovakia in particular, the Czech Republic does not have a substantial nationalist-oriented resistance towards NATO. Nevertheless, part of the nationalist-oriented resistance towards NATO was adopted by the discourse of the Czech left. At first sight, the nationalistically motivated negative attitude of the voters of the populist Republican Party is more a result of xenophobia and fear of Germany. These Republican voters would not object at all to NATO nor to the entry of the Czech Republic into NATO, if they did not see NATO as a sophisticated German tool to manipulate the country.

Table 3. How voters of political parties would vote in a hypothetical referendum on NATO entry (in percentage points)

\begin{tabular}{lcc} 
& \multicolumn{3}{c}{ vote for NATO entry } \\
Favoured political party & yes & no \\
\hline KSČM - Communist Party (Extreme Left) & 14 & 86 \\
ČSSD - Czech Social Democratic Party (Left) & 57 & 43 \\
KDU-ČSL - Christian Democratic Party (Centrist) & 67 & 33 \\
US - Union of Freedom (Right) & 94 & 6 \\
ODS - Civic Democratic Party (Right) & 92 & 8 \\
SPR-RSČ - Republican Party (National Extreme Right) & 21 & 79 \\
\hline
\end{tabular}

Source: $\quad$ STEM - September 1998 poll.

3) People can be correctly classified as supporters/opponents of admission to NATO on the basis of their political orientation (71 per cent) - result of Discriminant Analysis. 
Despite a significant split in the Czech Republic on the subject of NATO entry, there is a strong probability that the result of a hypothetical referendum would approve it, although the upper limit of support would be approximately $67 \%$ of adult inhabitants. A further growth of approval above this limit would need to come from changes in strongly opposed attitudes. This is very unlikely because these attitudes are very consistent. But even this higher threshold of support, that is, in a referendum, would depend on the level of willingness to participate in it.

The population of the Czech Republic feels relatively safe in the Central European region when compared with the Polish public, for example, and less abandoned than the public of Slovakia. Both in Slovakia and in the Czech Republic the data from public opinion polls reflect a novelty of the public thinking in a wider geopolitical context, and their heritage of geopolitical recklessness. The Central European region is perceived as safe. The majority of the population in the Czech Republic is convinced that there is no potential military threat to the country. This view is most prevalent among the young. Longterm monitoring of public opinion shows how sensitively the public perceives conflicts in their close neighbourhood, but also how quickly their worries die away once the conflicts are suppressed. This is true regardless of whether conflicts have really ended or are just in a temporary lull. Balkan countries were still considered a military threat in the middle of 1995 (15\% of respondents thought so) but in 1998 this fear has abated (now 4\%). And this is precisely at the time when a new conflict is about to break out. The majority of the population do not have major fears over possible effects resulting from the international situation on our security.

There is a widespread feeling in the Czech Republic that sources of military danger emanating from more remote areas (such as, for example, Islamic countries) cannot be underestimated. This is in contrast to Poland, but partly also to Hungary, where the public perceives a threat more from its immediate environs. The main source of threat though, according to public opinion research, is Russia (fixed at about almost a half of the adult population) and Germany (fixed at about one-fifth of the public). In reverse logic, the highest rate of trust (a feeling that there is nothing to worry about from that quarter) applies to the USA, but again also to Germany. Concern about Russia or Germany is not dispersed randomly, it is concentrated in certain segments of the population. Right-wing oriented people are afraid of Russia, and their concern about Germany is negligible, the situation among left-wing oriented people is reversed. Concern about Germany draws from resentment to their character and increases with age; the generation in their 60's is twice as fearful as those in their 30's. Nevertheless, the biggest concern among young people is about Russia. However, the sense of an external military threat coming from the side of Russia is, among the Czech public, as it turns out smaller than one might have expected. This seems to be due to several factors:

- The left-oriented part of the population rejects the thought of threat coming from Russia principally;

- The extreme right-wing, Republican-voting part of the population rejects it because they emphasise the threat coming from Germany;

- Another part of the population is not worried about the threat from Russia because they are convinced of its weakness.

What is specific about this is the fact that the bigger potential threat from outside is perceived more by the left-oriented part of the public. Their anxiety is not alleviated by join- 
ing NATO. Indeed, it is the existence of NATO that remains an important source of this anxiety, a view which in today's world can be regarded as an anachronism. The fears of these people are describable and are being described in the same language as could commonly have been heard before 1990. It is the discourse of the communist idea of the bipolarity of the world that has retained its terms of expression (warmonger, revanchism, capital interests) up until today. Even the sources of this anxiety are the same as in the past: the United States, France, Great Britain, and Germany, of course, as imperialist aggressors.

Neither concerns about the international political situation nor those about a direct attack on the country in a military conflict are the factors for the Czech public that would accelerate in the search for security under NATO umbrella. Attitudes towards NATO seem much more to be a question of the political orientation of people than their concerns about security risks. It is the political orientation of people that influences their concerns about a threat to the country and their attitude towards NATO (fears of a threat to the country thus is only an intervening variable). NATO membership is more of a guarantee for society of its irreversible turn away from the past. It is considered more a release from the potential risk of internal regression of the social system than a protection against external danger.

Motivation for gaining membership thus circle around questions of security insurance against external threats (especially from Russia), but also around the prospects of internal political stability of the country. It also stems from the idea that joining NATO could be a boost to its economic development. In this respect, Czechs do not differ so much from the populations of other aspirant countries, although their faith is much weaker than that of some (e.g. Romania, Albania) who see NATO (and the USA even more so) as a strong patron who will cure all their ills.

The attitude of the Czech Republic towards NATO is ambivalent in yet another respect. Correspondent analysis or results from various research into public opinion show how the public paradoxically inclines to inconsistent attitudes. The belief that the country should defend its sovereignty at any cost co-exists with the belief that any such attempt would nevertheless be futile in its chances of success. That is to say that in the end, the fate of such a small country as this is always decided by great powers. While half of respondents asked in a row of research studies believed that if we did not enter NATO the Czech Republic would be at the mercy of Russia, a similar though slightly smaller proportion think that NATO membership would help Germany to take over the country. There is always around half of the population with the opinion that the destiny of the country is either in the hands of one or the other great (regional) power. Inside NATO we are a toy in the hands of Germany, and outside and it would be Russia who would play with us. The belief in the influence of Germany and Russia on our destiny is strong, though only about 16 per cent express the opinion that the country is caught in a fatal trap between the great powers (without any chance of escape).

The analysis of research results from public opinion research agencies (e.g. STEM and Sofres-Factum) gives us a summary of the public's expectations towards NATO entry:

- A growing feeling of safety (namely from Russia). Part of the population - and it can be guessed that these are the opponents of joining NATO - is nonetheless convinced about the growth of the risk of military threat after admission to NATO. 
- A certain financial burden, or higher defence costs, than in the case of development of an independent defence, and as a result of this - higher taxes.

- Certain safety costs (nuclear weapons on Czech territory).

- Economic impulses arising from the increased attractiveness of the country for foreign investors, a growth of confidence in the Czech Republic for the developed countries of the world, and access to advanced technologies.

- Reduced sovereignty, subordination to other countries, dependence on them, but also NATO military bases stationed on Czech territory.

Using a discriminative analysis of analogous public opinion research data, an attempt was made to identify some of the consequences of acceptance into NATO. Such consequences that, as stressed and emphasised by respondents, signal whether these people are advocates or opponents of NATO entry. The goal of the analysis was to identify opinions that can sort people, whose attitude towards NATO is not known to us, into groups of supporters and opponents of NATO membership for the Czech Republic. In all the cases used, the discriminative ability of the selected indicators was very high (they helped us classify about 90 per cent of people - see Table 6$)^{4}{ }^{4}$

Table 4. Discriminant Analysis (Data from STEM Polls)

Eigenvalues and Wilks' Lambda

\begin{tabular}{lcccrrc} 
& \multicolumn{2}{c}{ Canonical } & Wilks' & & & \\
& Eigenvalue & Correlation & Lambda & Chi-square & df & Significance \\
\hline September 1998 survey & $4.467^{*}$ & 0.904 & 0.183 & 2602.539 & 8 & 0.000 \\
May 1998 survey & $1.226^{*}$ & 0.742 & 0.449 & 1239.248 & 11 & 0.000 \\
April 1998 survey & $2.505^{*}$ & 0.845 & 0.285 & 1333.193 & 8 & 0.000 \\
\hline
\end{tabular}

*) First 1 canonical discriminant functions were used in the analysis.

4) Tables no. 4-6 contain findings of three different polls. 
Table 5. Discriminant Analysis (Data from STEM Polls)

Coefficients

\begin{tabular}{|c|c|c|c|c|c|}
\hline \multirow[b]{2}{*}{ Variables used in Analysis } & \multirow[b]{2}{*}{ SCDFC } & \multirow[b]{2}{*}{ SM } & \multirow[b]{2}{*}{$\mathrm{CDFC}$} & \multicolumn{2}{|c|}{$\begin{array}{c}\text { CFC } \\
\text { (vote for NATO) }\end{array}$} \\
\hline & & & & yes & no \\
\hline \multicolumn{6}{|l|}{ Survey 1998, September } \\
\hline \multicolumn{6}{|l|}{ Joining NATO - } \\
\hline the best way to ensure national security & 0.700 & 0.857 & 2.966 & 26.561 & 39.575 \\
\hline \multicolumn{6}{|l|}{ Enlargement of NATO } \\
\hline definitely will remove the iron curtain & 0.226 & 0.457 & 0.657 & 12.088 & 14.970 \\
\hline Military presence of USA in Europe is necessary & ry 0.094 & 0.414 & 0.251 & 12.828 & 13.928 \\
\hline There are better ways to ensure national security & $y-0.212$ & -0.427 & -0.604 & 12.147 & 9.524 \\
\hline Enlargement of NATO is unnecessary & -0.147 & -0.431 & -0.423 & 13.019 & 11.161 \\
\hline \multicolumn{6}{|l|}{ We will be inferior to other countries } \\
\hline in NATO & -0.130 & -0.496 & -0.379 & 13.971 & 12.309 \\
\hline \multicolumn{6}{|l|}{ Germany will gain control over our country } \\
\hline in NATO & -0.079 & -0.334 & -0.202 & 6.145 & 5.258 \\
\hline NATO enlargement will split Europe again & -0.037 & -0.369 & -0.096 & 9.258 & 8.836 \\
\hline \multicolumn{6}{|l|}{ Survey 1998, May } \\
\hline Improving our prestige & 0.391 & 0.733 & 0.591 & 2.502 & 3.849 \\
\hline Accelerating economic growth & 0.179 & 0.576 & 0.250 & 3.854 & 4.424 \\
\hline \multicolumn{6}{|l|}{ Improving credibility of the country } \\
\hline for foreign investors & 0.170 & 0.614 & 0.250 & 1.116 & 1.735 \\
\hline Political stability in the country & 0.153 & 0.575 & 0.213 & 3.182 & 3.668 \\
\hline Improving the chances of joining EU & 0.034 & 0.428 & 0.050 & 0.430 & 0.545 \\
\hline Presence of Czech soldiers in military conflicts & -0.004 & 0.166 & -0.007 & 2.208 & 2.192 \\
\hline Foreign army in the Czech Republic & -0.052 & -0.385 & -0.064 & 1.375 & 1.229 \\
\hline Atomic weapons in the Czech Republic & -0.153 & -0.508 & -0.182 & 1.810 & 1.395 \\
\hline Unnecessary expenditure on defence & -0.248 & -0.614 & -0.332 & 3.450 & 2.692 \\
\hline Freedom of our country will be limited & -0.268 & -0.544 & -0.328 & 2.275 & 1,528 \\
\hline \multicolumn{6}{|l|}{ Survey 1998, April } \\
\hline The country will be powerless outside NATO & 0.549 & 0.712 & 1.660 & 10.188 & 15.443 \\
\hline Joining NATO is necessary for the economy & 0.217 & 0.403 & 0.523 & 4.832 & 6.486 \\
\hline Consent to NATO troops in the Czech Republic & c 0.096 & 0.358 & 0.240 & 8.046 & 8.806 \\
\hline \multicolumn{5}{|l|}{ Membership in NATO is more important } & 7.837 \\
\hline \multicolumn{6}{|l|}{ Consent to atomic weapons } \\
\hline in the Czech Republic & 0.042 & 0.267 & 0.109 & 7.854 & 8.197 \\
\hline Russia threatens our country & 0.030 & 0.207 & 0.064 & 3.465 & 3.667 \\
\hline Neutrality is the best solution & -0.296 & -0.560 & -0.789 & 15.104 & 12.605 \\
\hline In joining NATO we will lose our sovereignty & -0.461 & -0.616 & -1.289 & 15.049 & 10.968 \\
\hline
\end{tabular}

$\mathrm{SCDFC}=$ Standardised Canonical Discriminant Function Coefficients; SM = Structure Matrix;

$\mathrm{CDFC}=$ Canonical Discriminant Function Coefficients. 
Table 6. Discriminant Analysis (Data from STEM Polls) Classification Results

\begin{tabular}{|c|c|c|c|c|c|}
\hline \multicolumn{6}{|c|}{ Predicted Group Membership } \\
\hline Vote for NATO & & 1 yes & 2 no & Total & Correctly Classified \\
\hline \multicolumn{6}{|c|}{ Survey 1998, September } \\
\hline \multirow[t]{2}{*}{1 yes } & count & 912 & 65 & 977 & \\
\hline & $\%$ & 93.3 & 6.7 & 100.0 & \\
\hline \multirow[t]{2}{*}{2 no } & count & 26 & 535 & 561 & \\
\hline & $\%$ & 4.6 & 95.4 & 100.0 & \\
\hline \multirow[t]{2}{*}{3 ungrouped cases } & count & 6 & 11 & 17 & \\
\hline & $\%$ & 35.3 & 64.7 & 100.0 & 94.1 \\
\hline \multicolumn{6}{|l|}{ Survey 1998, May } \\
\hline \multirow[t]{2}{*}{1 yes } & count & 846 & 118 & 964 & \\
\hline & $\%$ & 87.8 & 12.2 & 100.0 & \\
\hline \multirow[t]{2}{*}{2 no } & count & 73 & 519 & 592 & \\
\hline & $\%$ & 12.3 & 87.7 & 100.0 & \\
\hline \multirow[t]{2}{*}{3 ungrouped cases } & count & 7 & 16 & 23 & \\
\hline & $\%$ & 30.4 & 69.6 & 100.0 & 87.4 \\
\hline \multicolumn{6}{|l|}{ Survey 1998, April } \\
\hline \multirow[t]{2}{*}{1 yes } & count & 506 & 52 & 558 & \\
\hline & $\%$ & 90.7 & 9.3 & 100.0 & \\
\hline \multirow[t]{2}{*}{2 no } & count & 40 & 471 & 511 & \\
\hline & $\%$ & 7.8 & 92.2 & 100.0 & \\
\hline \multirow[t]{2}{*}{3 ungrouped cases } & count & 161 & 296 & 457 & \\
\hline & $\%$ & 35.2 & 64.8 & 100.0 & 91.4 \\
\hline
\end{tabular}

Items where a positive selection predicts a positive attitude (a negative selection predicts a negative attitude) towards NATO are: the end of the division of Europe, the increased prestige of the country, the growth of the chances of being accepted into the European Union, interior political stability and a barrier to Russian expansion, the helplessness of the country without NATO membership, the necessity of membership for the economy of the country, advancement in trustworthiness for investors and speeding up the economic development of the country, external and internal security, confidence of an equal position of the country within NATO, and the feeling of the need for American presence in Europe. Items where a positive answer predicts a negative attitude towards NATO (negative selection predicts a positive attitude) are represented by the following consequences of NATO expansion or admission into NATO: being under the control of Germany, the division of Europe, excessive costs (and a feeling connected with this of the possibility to ensure the safety of the country by other means than by NATO entry), sovereignty loss, limitations to the freedom of the country, surrender to the interests of the great powers.

In the Czech Republic, opponents to NATO entry stress similar disadvantages and risks of such a step as those in Poland, Hungary and Slovakia. These are the alleged loss of sovereignty, and being taken over by Germany, but also the unacceptability of some assumed duties of member countries (a NATO military presence or nuclear weapons stationed on the territory of the Czech Republic) and risks arising out of membership. Above all, it is the assumption of a disproportionate economic load connected with joining NATO and membership. Risks, dependency, costs - this is a triad in which most of their argumentation oscillates. 
Here a typology can be identified of usual argumentation among people on the subject of NATO, according to whether they declare themselves as right-wing, left-wing, or in the centre:

- Left: NATO membership will reduce our sovereignty, and will lead to German control over the country. Again we will have foreign troops on our territory, and we will be subject to malice from Russia.

- Right: NATO membership will guarantee not only the security of the country against an external attack, but also its internal political stability, it will have economic benefits, and it will advance the attractiveness of the country leading to an inflow of foreign investment.

- Centre: NATO admission will lead to a growth in defence costs and to higher taxes. We will be forced to accept nuclear weapons on our territory, and the risk of the country getting involved in military conflicts will increase.

What do people think can replace NATO? If we offer the opponents of joining NATO the opportunity to consider other national security solutions than NATO membership, they cite most of all neutrality (37\%), also reliance on the Czech army (16\%), and on the Czech people in general. The situation is similar both in Hungary and Slovakia (not so much in Poland, or especially in Romania, where confidence in the great power cover of the USA has almost the character of resignation into reliable hands). Some less binding forms of guarantee are also present from the side of the great powers or pan-European defence. Neutrality is the least expensive form of securing the defence of the country in the eyes of the public. And this is so regardless of whether the public prefers NATO membership or not. It is the neutrality defenders who see the costs connected with joining NATO as unnecessarily high. The proportion of people who believe that NATO entry is the most costly way of securing the safety of the country is twice as high among the proponents of neutrality as among the advocates of NATO membership. Neutrality is, together with regional military co-operation, the solution to the security situation especially for the voters of left-wing parties. Namely for the voters of the Communist party, but also the voters of the Social Democrats are no less represented. This solution is also seductive to voters of the centre parties and to the populist Republicans.

The public (the media to be more precise ${ }^{5}$ ) discourse on the debate about NATO is played against the background of a search for a new national and state identity. However, it is strongly loaded with resentments and judgement of the past. It is not just one discourse that is represented here, but two competing discourses: to simplify it - left- and right-wing (in the sense of the classic concept of the left-right spectrum of political orientation). Nationalist discourse is also strongly present in the leftist discourse, but in contrast to other applicant countries (especially in contrast to Slovakia) it has little influence in itself. Its not numerous, autonomous bearers are concentrated around the Republican Party.

From research studies of public opinion we know the characteristics of bearers of this left-wing and nationalist discourse. They are mostly people who are socially marginalised, low educated, with a narrow scope of life view, and anomic. Right and left discourse develops independently and they compete only in a limited sense. Each of these

5) See Mareš (1999) or Alner (1998a, b), Vašečka (1998). 
two discourses has its own phraseology (metaphors, latent symbols) which reflects hopes and concerns, and oscillates between ideals and pragmatic attitudes. Thematically, both of the discourses concentrate around analogous themes:

- safety and risks.

- place in Europe, identity and sovereignty.

- cost (not only financial) and willingness to pay for it and benefit.

- values - orientation towards NATO entry is often more of an expression of wider considerations and thoughts on the place of the country within Europe and the world than a result of a feeling of threat.

\section{Conclusion}

The polarised public opinion means that the discussion on NATO membership takes place in two languages. The lesser represented left discourse concentrates around the lack of necessity of joining NATO when there are other (cheaper and safer) ways to secure the safety of the country. In contrast to Slovakia not even the left discourse points to cooperation with Russia as one of these ways. Not even the image of the country as a bridge between NATO and Russia is represented here, as is widespread in Slovakia. Russia is not presented as an ally (neither military nor even economic) in this discourse. It is only argued that NATO expansion endangers the natural interests of Russia. It refers to destabilisation of Europe and renewal of its division caused by the acceptance of the postcommunist countries into NATO. What is interesting is the fact that it is the left discourse that is soaked in worries and a feeling of military threat to the country (much more than the right-wing discourse). Pointing to the threat to Russia caused by NATO expansion indirectly enlarges this concern and spreads it even outside its discourse. NATO is evidently understood as a guarantee of the interests of capitalism. The core of objections is a loss of the sovereignty of the country after NATO admission, and a phobia of German control. In the background there can be felt some aversion to the values represented by NATO.

A sophisticated form of this discourse employs the possible costs of NATO admission. It is not only the Czech public but also the populations of other applicant countries and of individual member countries that are sensitive to reminders of financial sacrifice, the American public included. It is being indicated that nobody has ever worked out how much it costs to enter NATO and whether it would bring a decline in the standard of living. Membership is not rejected directly, it even has some manifest support (for example, among Social Democratic voters) but it is indicated that the government must respect public opinion in this case (as seen in the accent placed on organising a referendum, for example). This discourse is shared by both the left and the political centre (on the level of the media as well as on the level of opinions of people who are members of the centre).

Right-wing discourse stresses the importance of NATO values as well as the values of Europe that we want to return to. It stems not only from an identification with the values but also the interests of the Czech Republic and NATO. NATO admission is presented as a guarantee of not only external safety, but also internal stability. It is not then a threat but a guarantee of sovereignty. In the background there is a belief that only after NATO entry will the irreversibility of changes since 1989 be guaranteed. Great importance is given to expectations of an economic contribution - entry into NATO is a gateway to the European Union and thus also to prosperity. As with the left-wing discourse, 
where there was a clear purposeful call for a referendum, it is with clear purpose explained here that such a poll is not necessary. The reversal of the traditional trend is interesting; the right have taken over the paternalistic left-wing vision regarding the political inexperience and irresponsibility of the people, and the left have adopted the right-wing thesis of the sovereignty of the will of citizens. Unpleasant duties arising from NATO membership are admitted even in the right discourse. But neither acceptance of the possibility of the stationing of foreign troops or nuclear weapons on Czech soil are arguments against the NATO admission.

Secondary analysis of data from public opinion research studies indicates that there exists a hard core of the convinced - either of the necessity of entering NATO, or of the necessity of preventing such a step. Any attempt to win over people from either category, to the other one is a waste of energy. However, there is a large group of people, whose attitude towards the Czech Republic joining NATO is ambivalent, undecided, or who are indifferent to the issue, as they even may have not noticed it, or taken it into consideration. This potential is not negligible. Let us remind ourselves that the number of undecided oscillates between 20 and 30\%, and in research studies conducted regularly by Eurobarometer in the Czech Republic this figure has gone as high as 50\% (of those who do not know whether they would support or oppose the Czech Republic joining NATO in a referendum). There is a fertile field among them for missions from both the left and right. The answers of undecided persons to the discriminatory items show that about $40 \%$ of the people are strongly influencable. These people could indeed tip the scales either way. In one representative research study of public opinion, the data analysis has shown that among them about $26 \%$ are latent opponents to NATO entry, $33 \%$ are supporters of joining NATO, and the remaining roughly $40 \%$ cannot decided.

In summary, we can claim that even though the Czech public is not onedimensionally oriented towards NATO, as is the case of the Polish public, membership is still understood as the best strategy of achieving national security by a substantial part of the public. The Czech public would nevertheless be prepared to accept other forms of security arrangements. For example, some kind of one-sided guarantee from the side of NATO (without the actual membership of the Czech Republic in NATO), co-operation with smaller countries of the Central European region, or neutrality. The Czech left does not want co-operation with Russia, as is the case for the Slovak left, but rather tends towards independent defence or neutrality.

The question of joining NATO is connected with the question of becoming a member of the European Union. There are three numerous distinctive types (clearly formed and existing alongside less numerous groups of those who would give their support only to one of them) in the public:

- people who are at the same time for the admission of the country into both of the institutions representing European structures (EU and NATO) - about 40\%;

- people who are at the same time against the admission of the country to any of the institutions representing European structures (EU and NATO) - about 16\%;

- people who do not know how to decide in any of these cases - about $25 \%$.

Those who are decided on supporting entry into one of the mentioned institutions and do not support the other (or do not know how to decide in this case) are a very marginal 
group. Borders between the first and the second of the above mentioned distinctive types is again delineated by political orientation.

\section{Epilogue - one year after entry}

Table 7. Support for Czech membership of NATO - February 2000 (percentage points)

"Do you agree or disagree with the membership of your country in NATO?"

\begin{tabular}{lccc} 
& $\begin{array}{c}\text { Czech Republic } \\
\text { (IVVM) }\end{array}$ & $\begin{array}{c}\text { Hungary } \\
\text { (TÁRKI) }\end{array}$ & $\begin{array}{c}\text { Poland } \\
\text { (CBOS) }\end{array}$ \\
\hline agree & 49 & 61 & 63 \\
neither agree nor disagree & 19 & 23 & 18 \\
disagree & 26 & 10 & 12 \\
don't know & 6 & 6 & 7 \\
\hline
\end{tabular}

Source: $\quad$ Prague, IVVM February 28, 2000 (IVVM - Institute for Public Opinion Polls at the Czech Statistical Office; TÁRKI - Centre for Social Research; CBOS - Centre for Public Opinion Research).

Translated by Iva Šmídová

PETR MAREŠ is an associate professor and head of the Department of Sociology at the Faculty of Social Studies at Masaryk University in Brno (Czech Republic). He is interested in social problems, inequality, unemployment, poverty and the methodology of social sciences. He publishes in the Czech Sociological Review and is the author of two books: Unemployment as a Social Problem $(1994,1998)$ and Sociology of Inequality and Poverty (1999).

\section{References}

Alner, Juraj 1998a. "Roviny verejnej rozpravy o vstupe do NATO (The levels of public debates on the entry of Slovakia into NATO).” Pp. 81-86 in Slovensko v šedej zóne? Rožsirovanie NATO, zlyhania a perspektívy Slovenska, ed. by M. Bútora and F. Šebej. Bratislava: Inštitút pre verejné otázky.

Alner, Juraj 1998b. "Analýza verejnej diskusie - dokumenty (Analysis of public discussion documentation)." Pp. 87-97 in Slovensko v šedej zóne? Rozširovanie NATO, zlyhania a perspektívy Slovenska, ed. by M. Bútora and F. Šebej. Bratislava: Inštitút pre verejné otázky.

Kull, Steven 1997. "America on Expanding NATO: A Study of US Public Attitudes." PIPA (Program on International Policy Attitudes), University of Maryland, February 13, 1997: 4.

Mareš, Petr 1999. "Česká a slovenská média o vstupu země do NATO: obsahová analýza tisku před madridským summitem (The Czech and Slovak media on the entry of the Czech Republic into NATO)." Politologický časopis 6: 271-281.

Vašečka, Michal 1998. "Rozprava o NATO v Slovenských periodikách v rokoch 1995 až 1997 (A debate on NATO in Slovak Periodicals from 1995 to 1997)." Pp. 131-156 in Slovensko v šedej zóne? Rozširovanie NATO, zlyhania a perspektivy Slovenska, ed. by M. Bútora and F. Šebej. Bratislava: Inštitút pre verejné otázky. 